\title{
Animacja społeczno-kulturalna w środowisku zróżnicowanym etnicznie i kulturowo
}

\begin{abstract}
STRESZCZENIE
W artykule przedstawiono zagadnienie animacji jako pedagogicznej metody pracy środowiskowej w środowisku zróżnicowanym społecznie, kulturowo i regionalnie. Diagnoza środowiskowa pozwala identyfikować lokalne kapitały mogące stanowić oparcie dla grupy animatorów uczestniczących w projekcie społeczno-kulturalnym, którego celem była aktywizacja badanej społeczności lokalnej. W opracowaniu tym ukazana jest także rola instytucji kultury w regionie pogranicza kulturowego i etnicznego w odbiorze społecznym.
\end{abstract}

\section{Słowa kluczowe:}

animacja, społeczność lokalna, zróżnicowanie etniczne, instytucja kultury, praca kulturalno-oświatowa, zmiany społeczno-kulturowe

\section{ABSTRACT}

The article presents the problem area of animation as a pedagogical method of working in the environment which is differentiated as regards its social, cultural and regional aspects. The environmental diagnosis is meant to identify local capitals which can offer support for a group of animators participating in the socio-cultural project, whose goal was activation of the examined local community. The author shows the role of the institution of culture functioning in the region of cultural and ethnic frontier in the social reception

1 Edward Nycz, Instytut Nauk Pedagogicznych, Uniwersytet Opolski, Polska, edward.nycz@ uni.opole.pl. 


\section{Keywords:}

animation, local community, ethnic differentiation, institution of culture, cultural-educational work, socio-cultural transformations

\section{WPROWADZENIE}

Tytuł prezentowanego opracowania anonsuje jego strukturę. Złożą się na nią treści podejmujące wielowymiarowość zmian zachodzących nie tylko w kraju, ale także mających miejsce w konkretnych zbiorowościach ludzkich, w których są różnie rozumiane i podejmowane. Animacja społeczno-kulturalna może łagodzić traumę zmian, szczególnie w warunkach pogranicza kulturowo-etnicznego (tu: gmina Dobrodzień), które pomimo czasowego zżycia się mieszkańców może stać się zarówno miejscem współpracy, jak i konfliktu, dlatego kultura jest elementem spotkania dla mieszkańców badanej gminy i przestrzenią budowy nowych projektów społecznych.

\section{WIELOWYMIAROWOŚĆ ZMIANY JAKO WYZWANIE ANIMACYJNE}

Sytuacja obecnego społeczeństwa wchodzącego rozwiązaniami organizacyjnymi w (po)nowoczesność nie jest tak klarowna jak społeczeństw tradycyjnych. Dla przykładu polskie transformacje cywilizacyjne połączyły się w czasie z dokonującymi się pod koniec XX w. zmianami ideologiczno-politycznymi i społeczno-ekonomicznymi, które wyłoniły uczestników dobrodziejstw transformacji i tych, którzy obiektywnie (ale także w odczuciu subiektywnym) poczuli się zmarginalizowani (Wnuk-Lipiński, 2008, s. 271). Budowa innego niż dotychczas ładu policentrycznego wydała się dla ówczesnych elit pociągającym zamierzeniem modernizacyjnym (Radziewicz-Winnicki, 2004). Jednym z trudniejszych zadań okazało się połączenie interesów jednostek, organizacji formalnych i wyłaniających się nowych i nieznanych dotychczas reguł instytucjonalnych. Analizując aktorów nowego ładu III Rzeczypospolitej, zwrócić można uwagę na zdekomponowaną triadę, składającą się z: ludzi, instytucji i organizacji. Andrzej Rychard jest zdania, że zarysowana triada w sytuacji Polski końca XX w. uległa dekompozycji, a każdy z wymienionych elementów charakteryzował się odmienną logiką działania i racjonalnością (Rychard, 1995, s. 25-34). Demokracja i wolny rynek wznosiły „nowy” ład policentryczny, w którym reguły działania aktorów społecznych, organizacji i instytucji nie były jednak często zbieżne, asynchroniczne, a czasami wręcz przeciwstawne. Niedostatki 
występujące w systemach organizacyjnych, jak również w sferach reguł instytucjonalnych, dotyczyły całego wachlarza spraw ważnych dla funkcjonowania społeczeństwa. Rozpoczęła się - używając terminu Daniela Bella - „gra między aktorami” wyżej wymienionych sfer. Badania nad powodzeniem reform dowodzą, że zależą one od pozytywnego do nich nastawienia ze strony jednostek i grup społecznych. Badacze problemu wskazują, że postawy ludzkie cechować może aprobata dla zmian i podatność na nie lub obojętność, bierność i dezaprobata czy nawet gwałtowny opór. Proces jest więc grą o sumie zerowej, w której sukces jednych oznaczać również może porażkę innych (Krzysztofek, Szczepański, 2002, s. 41).

Zmiany w istocie swej mają to do siebie, że potrafią się przenikać, co jest widoczne w tzw. dylemacie trzech zegarów, na który zwrócił uwagę Ralf Dahrendorf (w odniesieniu do krajów postkomunistycznych), zauważając częstą desynchronizację pomiędzy powstaniem nowego systemu politycznego, systemu ekonomicznego i (u)kształtowaną mentalnością ludzi (Dahrendorf, 1991). Zmiana społeczno-kulturowa prowadzi również często do wystąpienia dysharmonii lub traumy kulturowej (Sztompka, 2000). Obserwując już z pewnej perspektywy czasowej polską transformację, można zauważyć erozję dawnego systemu mieszającą się z zauważalnymi ikonami nowoczesności na poziomie instytucjonalnym, organizacyjnym, ale i w aktywności jednostkowej. Doświadczenia wskazują, że potrzeba synchronizacji reform nie jest często możliwa w realnym czasie, na co wskazują nie tylko polskie doświadczenia (zob. Kojder, 2007).

Budowa społeczeństwa obywatelskiego nie jest prosta, gdy wychodzi się z monocentrycznego systemu polityczno-społecznego, dlatego w Polsce na przełomie wieków zauważono, że aktywizacja społeczna budująca różnorodne kolektywy stowarzyszeniowo-instytucjonalne może być ważnym elementem wytwarzającym pozytywny klimat dla zmian społeczno-kulturalnych i ekonomicznych. Marek S. Szczepański pisze, że powszechnie przyjmuje się, iż warunkiem niezbędnym dla nowej idei rozwoju społecznego jest partycypacja jednostek i wspólnot, którą można zidentyfikować badawczo w lokalnej demokracji samorządowej, zaliczanej do najważniejszych atrybutów społeczeństwa obywatelskiego (Szczepański, 1992, s. 66-67). Podstawą kształtowania się lokalnej wspólnoty obywatelskiej jest podmiotowość i terytorialność, a jej zakres wyznaczają dyspozycje psychospołeczne mieszkańców, które mogą być kształtowane w wyniku działania społeczno-kulturalnych instytucji publicznych. Nie bez znaczenia są opinie i działania lokalnych liderów, animatorów, autorytetów czy polityków, wpływających swoimi decyzjami na jakość działania wspólnoty lub instytucji.

W XXI w. można zauważyć, nie tylko wśród badaczy, rosnące zainteresowanie pracą instytucji kultury, oświaty i wychowania, które powinny kreować potencjał 
wspólnot lokalnych - formując ich kapitał społeczny (por. Radziewicz-Winnicki, 2007). Nawyki obywatelskie nabywane są przez młodych ludzi we wspólnocie lokalnej, w której decydującą rolę odgrywa tradycja osadzona w żywej kulturze oraz integracja społeczna ucząca zaufania niezbędnego do międzyludzkiej współpracy. Działania - w tym przypadku - instytucji kulturalno-oświatowych są również podstawą budowania podmiotowości. Rozwój społeczny zmienia człowieka i jego świadomość. Łatwiej jest zmienić „instytucje” niż „jednostkę”, szczególnie w sferze życia społecznego i kultury. Sfera kultury jest ważna ze względu na propagowane wartości (estetyka, etyka, sacrum), które decydują o człowieczeństwie. W planie modernizacji społecznej kultura jest ujmowana jako zespół wartości, wzorów i instytucji, które motywują ludzi do działania. Poza tym - warto spojrzeć z dawnej perspektywy - to kultura i dobre wychowanie może i powinno stanowić pomost dla ludzi w drodze do osiągnięcia dobrostanu duchowego i materialnego, jak już uważał w okresie międzywojennym Kazimierz Korniłowicz (Korniłowicz, 1930, s. 64-83). Czasy współczesne redukują pierwszą część wskazanego dobrostanu, kładąc nacisk na realizację drugiego w założeniach - konsumpcjonizmu oraz cynicznego bałwochwalczego postępu - zabijając w człowieku zdolność do „widzenia” rzeczy, jakimi one są rzeczywiście (szerzej: Frąckowiak, 2010, s. 52).

\section{ANIMACJA JAKO METODA PEDAGOGICZNA KREACJI ZRÓWNOWAŻONEGO ŚRODOWISKA}

W literaturze przedmiotu polskiej animacji poświęcona jest już duża liczba publikacji. Jednak opisy przeprowadzonych projektów i działań animacyjnych, jak też uwagi teoretyczne czasem bardzo się od siebie różnią. Od początku rozwoju animacji społeczno-kulturalnej trwa dyskusja teoretyków i praktyków nad tym, czym animacja jest i może być lub czym być powinna. W polskiej literaturze warto zapoznać się z próbami określenia jej w publikacjach m.in. Jana Żebrowskiego, Olgi Czerniawskiej, Małgorzaty Kopczyńskiej, Adama Nobisa, Janusza Gajdy, Zygmunta Łomnego, Józefa Kargula, Dzierżymira Jankowskiego, Barbary Jedlewskiej, Marii Mendel, Edwarda Nycza czy Bohdana Skrzypczaka.

Zawsze, gdy pojawia się jakaś nowa nazwa i użyteczna aktywność społeczna, rodzi się pytanie, czy oznacza ona pewne novum, czy też jest nową nazwą starej rzeczy (warto wskazać, że ideały animacyjne można zauważyć u dawnych organizatorów społecznych, np. Izabeli Czartoryskiej czy pedagogów społecznych, m.in. Heleny Radlińskiej, Kazimierza Korniłowicza, Aleksandra Kamińskiego)? 
Animacja od samych swoich francuskich początków (i innych krajów ówczesnej Europy Zachodniej) była złożonym zjawiskiem społeczno-kulturalnym - wyrażającym się różnorodnością jej działań. W tej różnorodności było i jest miejsce na kontynuowanie oraz stosowanie tradycyjnych działań społeczno-kulturowych, takich jak: wychowanie, samowychowanie (Balcer, 2018), edukacja, upowszechnianie kultury, ale i aktywizacja oraz aktywność określonych grup lub społeczności.

Animacja ma bezpośredni związek z charakterem współczesnego społeczeństwa - masowego, anonimowego, wyalienowanego, w którym jest typem praktyki nakierowanej na ożywienie, pobudzenie, wzmocnienie aktywności społecznej, stosowanej przez pracowników instytucji państwowych, samorządowych, społecznych, prywatnych, jak też przez działaczy nieformalnych. Próbując określić animację, można wskazać, że jest to: zachęcanie, wspomaganie, stymulowanie jednostek i grup do samodzielnego decydowania, projektowania i realizowania działań, które same uznają za pożądane i we wzajemnym zaufaniu współdziałają w jego realizacji. Pojęcie animacji w tym wypadku kieruje uwagę na sprawy wspólnotowe w działaniach ludzkich w określonej przestrzeni społeczno-kulturowo-geograficznej. Można szukać związków praktycznych pomiędzy celami animacji a kształtowanym kapitałem społecznym, szczególnie w zakresie budowy zaufania stanowiącego ważny element więziotwórczy opierający się na wspólnych wartościach (Sztompka, 2007; 2016).

Elementy kształtowania zaufania i więzi międzyludzkich ważne jest szczególnie na obszarach pogranicza etnicznego i kulturowego, gdzie tzw. długie i krótkie trwanie zbiorowości wskazuje na wysoki stopień skomplikowania stosunków społecznych (Szczygielski, 2006; Nycz, 2010). Życie społeczne w regionie kulturowo i społecznie zróżnicowanym jest w oczach pedagogów elementem wzbogacającym człowieka przy założeniu chęci wzajemnego zrozumienia i współdziałania. Sytuacja na obszarach pogranicza ulega szybkim zmianom w wyniku przemian zachodzących za sprawą procesów globalnych, ale i zmian krajowych. Animacja ma pomagać w akceptowaniu zmian lub tonizowaniu niepokojów ludzkich przy ich dokonywaniu (Nycz, 2013b, s. 187-227). Zrozumienie świata poprzez pobudzenie jednostek do aktywizacji, do samodzielnych działań ukierunkowanych na zaspokojenie potrzeb społecznych, kulturalnych lub religijnych w ich własnych środowiskach.

Działalność animacyjna ma więc wspomagać samowychowanie, samorozwój, autokreację dla twórczego (wzniosłego) życia kulturalnego ludzi w publicznych formach życia społecznościowego. Animacyjne środki i sposoby działania są różnorodne, tak jak różni są ludzie, ich potrzeby i pragnienia; jak różne są tradycje kulturowe, systemy wartości, style życia; jak różny jest ustrój społeczno-eko- 
nomiczny (Skrzypczak, 2006, s. 71-90). Jak wskazuje Małgorzata Kopczyńska - „animacja nie jest nową techniką, metodą dodaną do tych, którymi dysponują już pracownicy sektorów kultury, społecznego, wychowawczego czy socjalnego. Odnosi się ona raczej do sposobu, w jaki te osoby wykonują swoje prace, do ich postaw. Jej cechą charakterystyczną jest uznanie za pierwszorzędne potrzeb i interesów osób, których animacja dotyczy. Jej wymiar etyczny implikuje pozostawanie do dyspozycji uczestników i zaangażowanie, a nie - ukrywanie konfliktów" (Kopczyńska, 1993, s. 61).

Warto kończąc ten wątek zauważyć, że animacja społeczno-kulturalna rodziła się w podobnym czasie i miejscu, jak socjologia działania (akcjonalizmu) Alaina Touraine’a (lata 60. XX w.), która wyrastała z przekonania, że rolą i zadaniem socjologii jest aktywne uczestniczenie w procesach społecznych (ruchy społeczne) swojej epoki (Touraine, 2010). Akcjonaliści wskazywali, że powinno się pomagać aktorom społecznym w przezwyciężeniu własnych ograniczeń poznawczych, które mogą blokować grupowe działania.

Od lat 90. XX w. w Polsce animacja była również wiązana z nowym podejściem w zarządzaniu i organizacji życia kulturalnego wspierającego rozwój lokalny miast, miasteczek i wsi. Lokalny świat społeczno-kulturalny obciążony globalnymi wyzwaniami stanowi ciekawy temat badawczy. Dla organizatorów życia lokalnego ważna staje się identyfikacja kapitałów społecznych. Jeszcze stosunkowo niedawno zaszłości historyczne i ich etniczne konsekwencje (zob. Śmiełowska, 1999; Szmeja, 2000; Lis, 2015) stanowiły pewien problem społeczny w niektórych gminach Śląska Opolskiego (Nycz (red.), 2005). Obecnie - międzygrupowe relacje w całej swej rozciągłości - są dość dobrze opisane w literaturze socjologicznej (zob. Sołdra-Gwiżdż, 2010, s. 236-250).

\section{GMINA MIEJSKO-WIEJSKA W ŚWIETLE WYBRANYCH WYNIKÓW BADAŃ TERENOWYCH}

W 2017 r. w ramach projektu „Program Narodowego Centrum Kultury. Dom Kultury+. Inicjatywy lokalne” przeprowadzono autorskie badania wśród mieszkańców gminy miejsko-wiejskiej Dobrodzień (województwo opolskie, powiat oleski). Gmina liczyła 9717 mieszkańców, z których dwie trzecie zamieszkuje 12 sołectw. Od 2002 r. liczba mieszkańców zmalała o 9,2\%, a średnia wieku osiągnęła 41,7 lat. Stanu wolnego jest 29,3\% mieszkańców gminy, 57,1\% żyje w małżeństwie, 2,8\% mieszkańców jest po rozwodzie, a 9,9\% to wdowy/wdowcy. Liczba zawieranych małżeństw do liczby rozwodów wynosi 3,6 na 1000 mieszkańców. 
W wieku produkcyjnym jest 64,6\% mieszkańców gminy, 16,1\% - w wieku przedprodukcyjnym, a 19,3\% mieszkańców jest w wieku poprodukcyjnym (http://www. polskawliczbach.pl/gmina_Dobrodzien..., dostęp: 20.05.2018).

Mieszkańców charakteryzuje zróżnicowana tożsamość etniczna, będąca konsekwencją dziejową zmiennej przynależność administracyjnej. Obszar badań do II wojny światowej był terenem pogranicza niemiecko-polskiego. W latach 1975-1998 gmina przynależała do województwa częstochowskiego. W roku 2009 w gminie wprowadzono język niemiecki jako język pomocniczy, co było konsekwencją wyników Narodowego Spisu Powszechnego z 2002 r., gdyż 20,9\% mieszkańców zadeklarowało narodowość niemiecką. W spisie z 2011 r. wielkość ta wyniosła poniżej 20\% (Lis, 2015, s. 186-187). Obecna (2018 r.) burmistrz gminy jest osobą rekomendowaną przez mniejszość niemiecką (gminna frekwencja wyborcza 34,04\%, komitet wyborczy mniejszości niemieckiej otrzymał 23,9\% głosów).

W wykonanym sondażu diagnostycznym techniką badawczą był wywiad standaryzowany, realizowany przez nieprobabilistyczny dobór próby „kuli śniegowej” (N: 138). Bazę danych i obliczenia zrealizowano w programie IMB SPSS. Wśród respondentów tylko co piątą osobą był mężczyzna, co trzecia osoba była w wieku do 30 lat, a co czwarta powyżej 50 roku życia. Co trzecia osoba była panną lub kawalerem (31,2\%), a ponad połowa (60,9\%) zamężna lub żonata. Co trzecia osoba miała wykształcenie poniżej średniego, średnie deklarowało $26,1 \%$, a wyższe $30,4 \%$ badanych. Osób pracujących było 61,7\%, uczących i studiujących - 27,8\%, pozostali byli emerytami; 97,7\% badanych deklarowało wiarę i (zróżnicowany) stopień uczestnictwa w praktykach religijnych. Autodeklaracja tożsamości etnicznej wskazuje na przywoływany teren pogranicza, gdyż 38,8\% badanych uważało

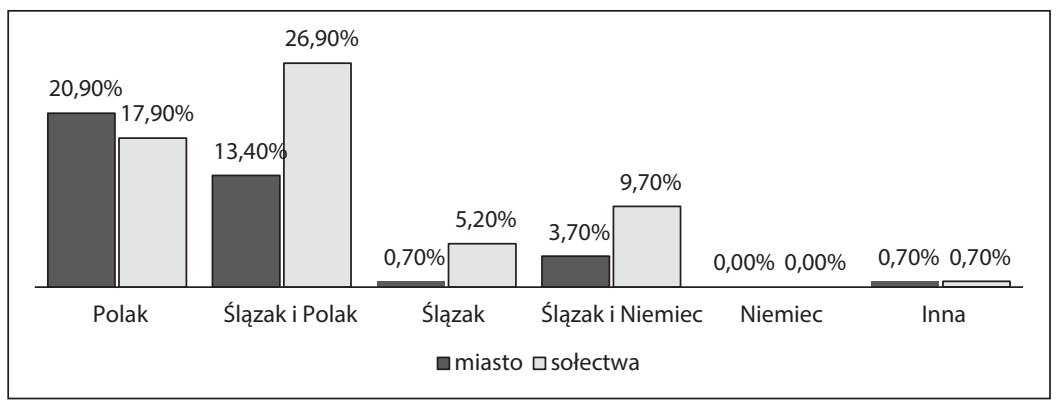

Wykres 1. Autoidentyfikacja badanych osób z uwzględnieniem miejsca zamieszkania (N: 138; \% z całości)

Źródło: opracowanie własne. 
się za Polaków, 40,3\% za Polaków i Ślązaków, 6,0\% za Ślązaków, 13,4\% za Ślązaków i Niemców, a 1,5\% za Ślązaków i Europejczyków (,inna”). Badania nie są metodologicznie reprezentatywne, co wynika z doboru próby, ale na pewno odzwierciedlają tendencje ujawnione w Narodowym Spisie Powszechnym z 2011 r. (zob. Łodziński, Warmińska, Gudaszewski (red.), 2015).

Dane wykresu 1 wskazują pewne zróżnicowanie pomiędzy autoidentyfikacją badanych z środowiska miejskiego i wiejskiego. Przeważa opcja śląska z kwalifikatorami będącymi wynikiem pogranicznego ulokowania badanego terenu i identyfikacji ludzi tu mieszkających.

Badani mieszkańcy są ogólnie zadowoleni z zamieszkania w gminie. Rysuje się statystyczna różnica pomiędzy badanymi mieszkańcami miasta (M /średnia arytm. skali 1 tak -5 nie/ = 1,88; $\mathrm{S}$ /odchylenie stand./ = 0,965) i sołectw $(\mathrm{M}=1,98 ; \mathrm{S}=$ 01,107). Test $t$ dla prób zależnych wskazuje wartość 3,592, co stanowi podstawę do odrzucenia hipotezy o braku różnic pomiędzy wyodrębnionymi środowiskami. Respondenci są również związani emocjonalnie z miejscem zamieszkania. Tu również rysuje się różnica wynikająca z miejsca zamieszkania (miasto $\mathrm{M}=2,09$, $\mathrm{S}=0,883$; sołectwa $\mathrm{M}=2,48, \mathrm{~S}=1,125$; test $t 7,739$ ). Przeprowadzona analiza wskazuje, że o ile wybory pozytywne są wysokie, to są jednak wewnętrznie zróżnicowane w sytuacji badanych z sołectw (analiza dyspersji). Tylko co dziesiąta badana osoba deklarowała chęć opuszczenia terenu gminy. Wyniki badań potwierdziły pewne tendencje występujące w środowiskach małomiasteczkowych i wiejskich Opolszczyzny. Dla przykładu mieszkańcy wskazują, że sami rozwiązują rodzące się problemy poprzez: zaangażowanie mieszkańców (zebrania, wybory, pomoc w sytuacji nieszczęścia...) na rzecz własnej miejscowości, deklarowane jest silniejsze zaangażowanie w realizowane projekty gminne mieszkańców, „determinizm” sytuacji zamieszkania kształtuje współpracę sąsiedzką, po utrzymywanie większego porządku na własnych posesjach i przestrzeni publicznej. Uciążliwa czasem kontrola sąsiedzka ma w tym wypadku pozytywne efekty w codzienności bezpiecznego dobrostanu funkcjonowania całej wspólnoty.

W sytuacji obszarów wiejskich aplikowana jest często duża liczba projektów z różnych programów (np. Odnowa Wsi, Lider+), które zmieniają i modernizują świat życia mieszkańców tych społeczności. W procesach zmiany w środowisku wiejskim znaczącą rolę odgrywa bezpośredni kontakt oraz hierarchiczny przekaz innowacji lub idei zmian. Badania w środowiskach wiejskich wskazują, że nie zawsze pojawiają się liderzy czy animatorzy wskazanych procesów. Badania prowadzone wśród sołtysów województwa opolskiego wskazują na przykład, że są oni wyrazicielami opinii wspólnoty i inspiratorami działań w sołectwach (Nycz, 2008, s. 319-377). 
W badaniach środowiska małomiasteczkowego i wiejskiego Opolszczyzny w 2017 r. pojawiają się osoby i instytucje, które stają się naturalnymi liderami lub animatorami modernizacyjnych zmian w społecznościach. Dobrodzień jest tzw. gminą zasiedziałą przez dawną ludność autochtoniczną (śląską, mniejszość niemiecką) oraz napływową, która z czasem zintegrowała się z elementem miejscowym.

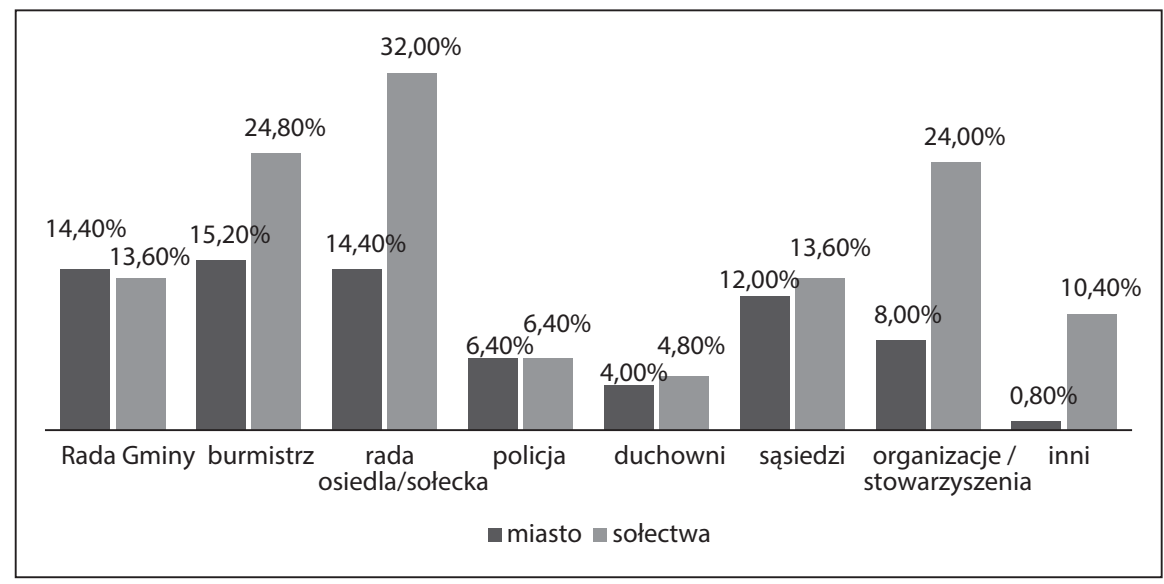

Wykres 2. Osoby lub instytucje wspomagające rozwiązywanie problemów społecznych z uwzględnieniem miejsca zamieszkania (N: 138; \% z całości)

Źródło: opracowanie własne.

We wskazaniach badanych ujawnia się synergiczność działania - instytucji, organizacji i pojedynczych ludzi. Działania zapoczątkowują najczęściej pojedyncze osoby będące liderami w swoich małych środowiskach. Ich działalność jest wspomagana lub wzmacniana przez organizacje społeczne (Ochotnicze Straże Pożarne, mniejszość niemiecka, stowarzyszenia rozwoju wsi), a następnie dopiero przez lokalne układy samorządowe lub polityczne. W środowisku wiejskim na uwagę zasługuje eksponowanie możliwości „ciał kolegialnych” w rozwiązywaniu lokalnych problemów. Badania przeprowadzono w pewnej części wśród sensu largo naturalnych animatorów życia społeczno-kulturowo-gospodarczego, którzy wskazali na zasoby „własnych” wspólnot lokalnych, eksponując najczęściej ich mocne strony. Podkreślali przy tym aktywność samych mieszkańców i zróżnicowane historyczno-kulturowe zasoby społeczności. Same społeczności są zróżnicowane społecznie i kulturowo, ale elementem je łączącym jest aktywność liderów i organów mobilizujących mieszkańców do działania, które wzmacnia dobrostan (indywidualne odczuwanie szczęścia i satysfakcji) życia mieszkańców. 
Władze lokalne powinny wspierać rodzące się i realizowane inicjatywy lokalne, gdyż budują one kapitał społeczny i minimalizują konfliktogenne koszty rozwoju społecznego.

Na szczególną uwagę zasługuje lokalny ośrodek kultury i sportu, który jest w praktyce centrum koordynacji działań kulturalno-oświatowych w gminie oraz uczestnictwa osób tu mieszkających w życiu kulturalnym. Dla badanych mieszkańców jest to miejsce realizacji pierwszego (tzw. pierwotnego, face en face) i drugiego (instytucjonalnego) układu uczestnictwa w kulturze (wg Antoniny Kłoskowskiej, 1981). Rozróżnienie układów kultury to efekt analizy empirycznych kontaktów ludzi z wytworami kultury, a poprzez te wytwory z kolejnymi ludźmi (zob. Niżnik, 1983, s. 100). Uczestnicy badań korzystają z oferty Dobrodzieńskiego Ośrodka Kultury i Sportu lub jego świetlic. Mieszkańcy miasta korzystają częściej z placówki głównej $(\mathrm{M}=2,04)$ a mieszkańcy wsi $(\mathrm{M}=2,41)$ z jej filii - świetlic (w tym 17,0\% w stopniu znacznym). Niepokoić może to, że co trzeci mieszkaniec wsi i co dziesiąty miasta nie korzysta z lokalnej infrastruktury kulturalnej. Mieszkańcy miasta są bardziej zadowoleni $(\mathrm{M}=1,91, \mathrm{~S}=0,925)$ z pracy placówek niż osoby ze wsi $(M=2,13, S=1,024)$. Poglądy na funkcjonowanie wskazanych placówek z uwzględnieniem deklaracji tożsamościowej obrazują dalsze wyniki.

Tabela 1. Działalność placówki kultury w gminie w odbiorze badanych z uwzględnieniem ich autoidentyfikacji (średnia. arytm. kontinuum skali 1 bardzo zadowolony - 5 niezadowolony)

\begin{tabular}{lllllll}
\hline Zagadnienia & \multicolumn{3}{l}{ Deklarowana tożsamość } & & \\
\cline { 2 - 6 } & & $\begin{array}{l}\text { Ślązak } \\
\text { i Polak }\end{array}$ & Ślązak & $\begin{array}{l}\text { Ślązak } \\
\text { i Niemiec }\end{array}$ & inna & \\
\hline A & $\begin{array}{l}\text { Korzystanie z oferty lokalnego } \\
\text { ośrodka kultury lub jego świetlic }\end{array}$ & 2,06 & 2,28 & 3,13 & 2,56 & 1,00 \\
\hline B & $\begin{array}{l}\text { Zadowolenie z warunków funk- } \\
\text { cjonowania lokalnego ośrodka } \\
\text { kultury lub jego świetlic }\end{array}$ & 1,94 & 1,98 & 2,50 & 2,33 & 2,50 \\
\hline
\end{tabular}

Źródło: opracowanie własne.

Prawie wszyscy respondenci byli „klientami” ośrodka kultury i zdecydowanie wyrażali opinię o zadowoleniu z jego pracy. Szczegółowy opis społecznego odbioru funkcjonowania placówki kultury przedstawia tabela 2.

Dominanty w pracy placówki kultury w odbiorze społecznym uwzględniającym uwarunkowania tożsamościowe zestawia tabela 2. Osoby deklarujące tożsamość śląską są najmniej zainteresowane tym, co dzieje się w tej placówce, w przeciwieństwie do osób z grupy polskiej (i nielicznej europejskiej). Dane liczbowe 
Tabela 2. Ocena działalności głównej placówki kultury w gminie przez badanych z uwzględnieniem ich autoidentyfikacji (średnia arytm. kontinuum skali 1 bardzo zadowolony - 5 niezadowolony)

\begin{tabular}{lllllll}
\hline \multirow{2}{*}{$\begin{array}{l}\text { Zagadnienia } \\
\text { Polak }\end{array}$} & \multicolumn{3}{l}{ Deklarowana tożsamość } & & \\
\cline { 2 - 7 } & & $\begin{array}{l}\text { Ślązak } \\
\text { i Polak }\end{array}$ & Ślązak & $\begin{array}{l}\text { Ślązak } \\
\text { i Niemiec }\end{array}$ & inna & \\
\hline A & Oferty zajęć dla młodzieży & 2,51 & 2,40 & 3,43 & 2,00 & 1,50 \\
\hline B & Oferty zajęć dla seniorów & 2,78 & 2,60 & 3,00 & 2,75 & 1,50 \\
\hline C & Rozwijania pasji mieszkańców & 2,40 & 2,57 & 3,57 & 2,67 & 2,00 \\
\hline D & $\begin{array}{l}\text { Otwartości na współpracę z miesz- } \\
\text { kańcami }\end{array}$ & 2,38 & 2,27 & 3,14 & 2,12 & 2,00 \\
\hline E & $\begin{array}{l}\text { Zaangażowania pracowników ośrodka } \\
\text { kultury }\end{array}$ & 1,80 & 2,06 & 2,71 & 2,19 & 2,00 \\
\hline F & $\begin{array}{l}\text { Imprezy organizowane przez ośrodek } \\
\text { kultury }\end{array}$ & 1,96 & 2,06 & 2,86 & 2,00 & 2,00 \\
\hline G & $\begin{array}{l}\text { Polityka informacyjna o tym, co się } \\
\text { dzieje w ośrodku kultury i sportu }\end{array}$ & 2,08 & 2,06 & 4,00 & 2,65 & 2,00 \\
\hline
\end{tabular}

Źródło: opracowanie własne.

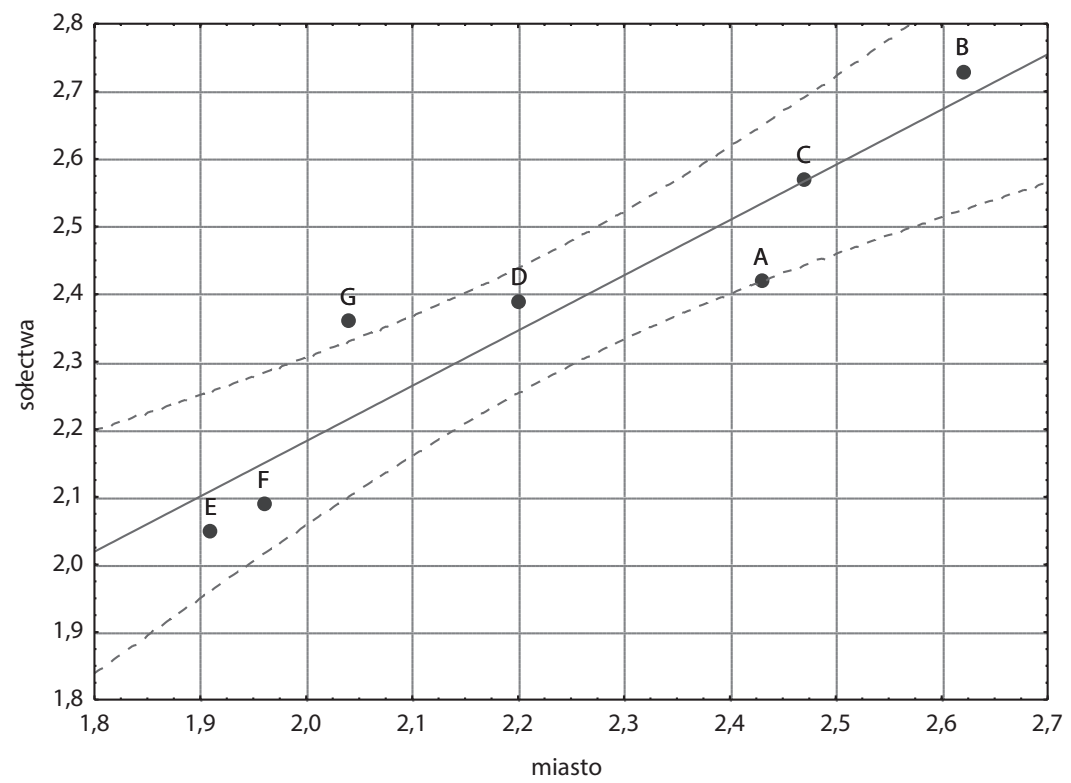

Wykres 3. Ocena pracy ośrodka kultury w wybranych zakresach z uwzględnieniem podziału na środowisko (średnia arytm. skali 1 bardzo zadowolony - 5 niezadowolony).

Uwaga: kody literowe z oznaczeń tabeli 2.

Źródło: opracowanie własne. 
wskazują na ogólnie wysoką ocenę odbioru pracy placówek kultury w gminie, ale przy pewnym wewnętrznym rozproszeniu wskazań. Pomiędzy środowiskami miasta i sołectw występuje wysoka korelacja $(\mathrm{R}=0,935$ istotne $\mathrm{z} \mathrm{p}<0,05)$. Ogólnie - bardziej zadowoloną grupą z pracy placówki są ludzie młodzi. Seniorzy, stanowiący bardzo ważną grupę w pracy ośrodka kultury, w tym przypadku mieszkańcy sołectw, nieco wyżej ocenili ofertę do nich skierowaną (34,45\%) niż badani z miasta (30,26\%). Wysoko oceniane jest zaangażowanie samych pracowników instytucji w upowszechnianie kultury. Ocena środowiska wiejskiego (45,38\%) jest ponownie wyższa od miejskiego (40,34\%).

Środowisko wiejskie jest bardziej zadowolone z organizowanych imprez (45,00\%) niż miejskie (36,67\%). Różnica być może wynikać z braku kontaktu z czwartym układem kultury, tzw. zamiejscowym (zob. Kłoskowska, 1981; Niżnik, 1983, s. 100-101) i zadowoleniem w rozrzuconych terytorialnie i małych liczebnie osadach z pracy świetlic, szczególnie na rzecz małych dzieci i osób starszych. Co trzeci badany w obu analizowanych środowiskach wysoko ocenia politykę informacyjną i promocyjną ośrodka kultury i sportu, która obejmuje wiadomości ustne, plakatowe, informacje przekazywane medialnie i internetowo do zainteresowanych osób.

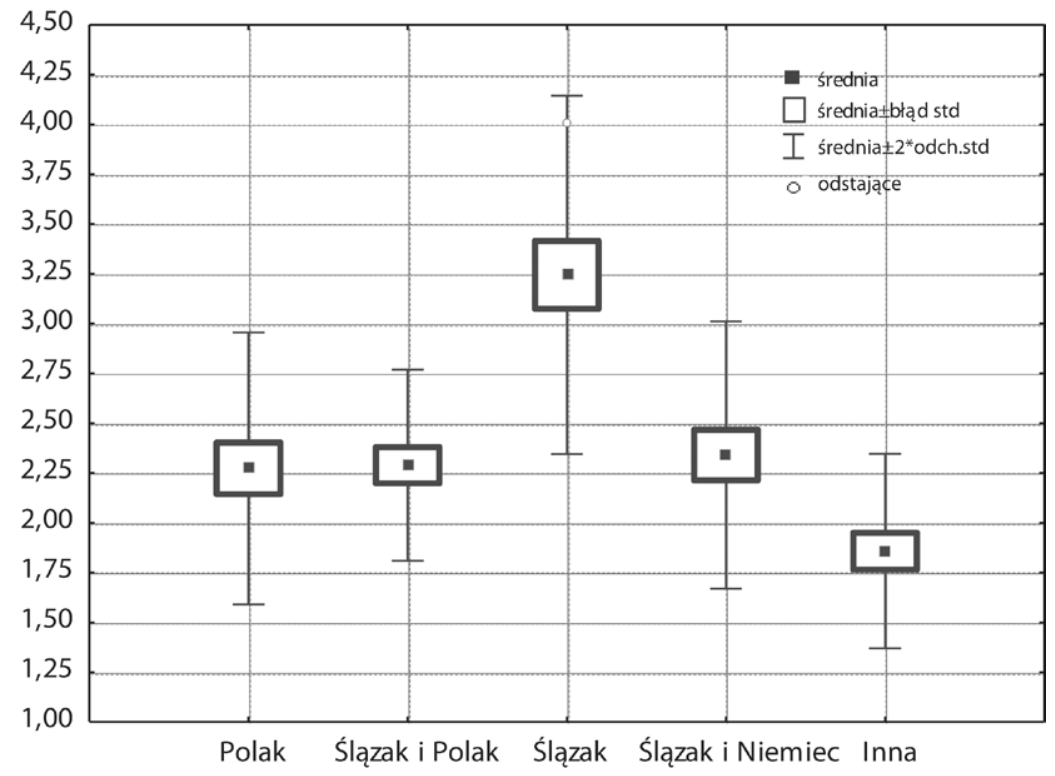

Wykres 4. Analiza skupień średnich arytmetycznych ocen działalności placówki kultury w gminie przez badanych z uwzględnieniem ich autoidentyfikacji (średnia arytm. skali 1 bardzo zadowolony - 5 niezadowolony)

Źródło: opracowanie własne. 
Ciekawie przedstawia się analiza zmiennej etnicznej. Wnioskowanie ze skupień poszczególnych średnich arytmetycznych (wykres 4) wskazuje na lepszą znajomość i uczestnictwo w kulturze badanych opcji polskiej, śląskiej ze wskazaniem polskim lub niemieckim niż identyfikujących się (tylko) jako Ślązacy.

Respondenci wykazali się również znaczną wiedzą o imprezach mających miejsce w badanej gminie (w sumie 326 wskazań). Deklaracje wskazywały, że badani są zainteresowani projektami realizowanymi przez placówkę, w tym w takich, które celowo byłyby skierowane do społeczności lokalnych. Znajdowało to odzew we wskazaniach imprez, które chciano by zrealizować u siebie przez wiodącą placówkę kultury i sportu. Zdecydowanie opowiadały się za tym środowiska sołeckie (38,01\%) niż miejskie (23,97\%). W sołectwach 38,5\% respondentów było zadowolonych (tylko 5,2\% było niezadowolonych) z warunków funkcjonowania lokalnych świetlic wspieranych przez placówkę główną, a w samym mieście zadowolenie z jej funkcjonowania wskazało 29,3\% respondentów.

Artykuł pragnę zakończyć rozważaniami poświęconymi ocenie przez badanych działalności lokalnych władz samorządowych. To one są możliwym promotorem prac budujących kapitał społeczny w gminie.

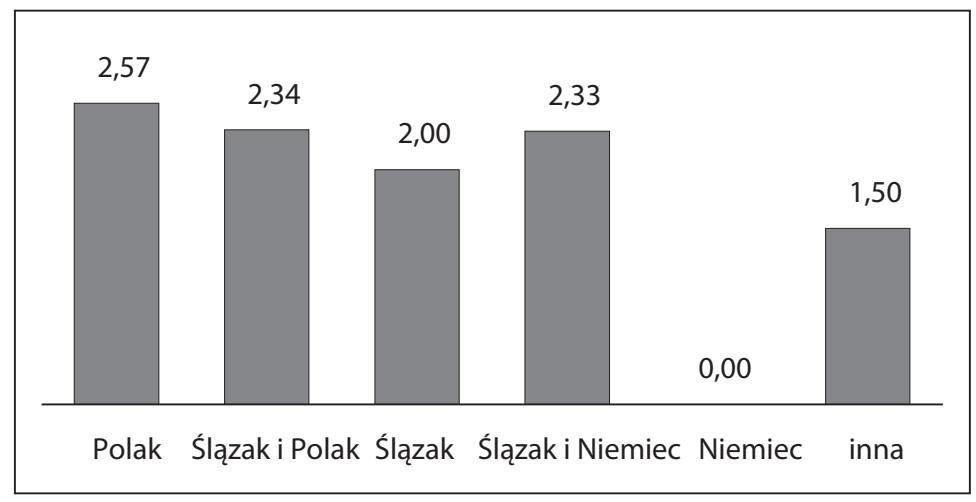

Wykres 5. Ocena działalności władz samorządowych obecnej kadencji przez badanych z uwzględnieniem ich autoidentyfikacji (średnia arytm. kontinuum skali 1 bardzo dobrze - 5 bardzo źle)

Źródło: opracowanie własne.

Prawie dwie trzecie badanych (63,3\%) jest zadowolonych z funkcjonowania lokalnego samorządu. W grupach tożsamościowych sytuacja jest wewnętrznie zróżnicowana, co ukazują dane wykresu 5. Ślązacy (62,5\% w grupie), Ślązacy opcji niemieckiej (88,9\%) są bardziej zadowoleni niż Polacy $(78,8 \%)$ i śląscy Polacy 
(75,9\%) z działań samorządu lokalnego. Zadowolenie to powiązane może być z emocjonalnym poparciem dla lokalnych komitetów wyborczych, które powołano w ramach głosowania w 2014 r. a obecnie ich przedstawiciele sprawują władzę (dane: http://samorzad2014.pkw.gov.pl, dostęp: 20.05.2018).

\section{ANIMACJA W GMINIE - PODSUMOWANIE BADAŃ}

Podsumowując rolę animacji w badaniu, opisie i działaniu w konkretnym środowisku życia trzeba stwierdzić, że w praktyce powinna ona realizować ludzkie potrzeby i marzenia. Analizując opisy oddziaływań animacyjnych można konstatować, że animacja to dziejąca się zmiana (Nycz, 2013a, 2013b). Początkiem animacji jest diagnoza, która przeradza się w działanie i realizację projektu. Doświadczenia badawcze uzyskane w czasie realizacji (nie tylko) przywołanego projektu wskazują, że potrzeba animacji rodzi się tam, gdzie należy ludzi adaptować do nowych wyzwań i zadań, aktywizować społeczno-kulturalnie i artystycznie, integrować w miejscu życia oraz wspierać, wspomagać, budować partnerstwo społeczne, ale i pozytywnie dowartościować zabawę i wczasowanie, podnosząc ogólny dobrostan życia jednostkowego i zbiorowego.

Gmina Dobrodzień jest pozytywnie oceniana jako miejsce życia i zamieszkania (szczególnie przez starszych). Stwarza ona również dobre warunki pracy dla animatorów i pracowników kultury w prowadzonych placówkach kulturalno-oświatowych i sportowych. Mieszkańcy badani pozytywnie w sumie ocenili pracę instytucji i jej kadry w upowszechnianiu nie tylko kultury lokalnej, ale i popularnej oraz symbolicznej. Mieszkańcy szczególnie niewielkich miejscowości bardzo cenią sobie kontakt z kulturą, rozrywką i zabawą, które stanowią element socjalizacji dla wzrastającego pokolenia oraz realizacji czasu wolnego w starszym pokoleniu. Działalność ośrodka kultury z filiami, wspieranego przez lokalną samorządność, jest nie do przecenienia w czasie atrofii lub „pękania” więzi społecznych. To pracownicy kultury (animacyjnie nastawieni w swojej pracy) lub animatorzy nieprofesjonalni są grupami, które poprzez własne zaangażowanie mogą odbudowywać lokalne więzi społeczne, w chwilach spotkań ludzi w przestrzeniach kultury. Budowanie więzi przez kolektywne inicjowanie i realizowanie sensów oraz przeciwstawianie się izolacji jest celem animacji samym w sobie.

Animacja to idea, coraz bardziej współcześnie pożądanego spotkania - JA i TY - w przestrzeni kultury, w której możliwe jest kształtowanie osobowości w oparciu o świat kultury, człowieka refleksyjnego i uczuciowego, nowoczesnego, ale i odpowiedzialnego za swój los i położenie innych. Charakterystyczne 
dla gminy Dobrodzień uwarunkowania tożsamościowe mieszkańców właściwie nie powodują żadnych pejoratywnych sytuacji w pracy instytucji kultury, jak również w szerszym odbiorze publicznym. Praca animatorów profesjonalnych i nieprofesjonalnych stanowi element pedagogicznej pracy w środowisku, które staje się środowiskiem „zrównoważonym” społecznie-kulturowo-wychowawczo. Utożsamianie się mieszkańców z własnym miejscem zamieszkania (procentowo w grupach wysokie), gdzie działa czynny samorząd, pracują instytucje i organizacje kultury, sportu, oświaty oraz pojawiają się animatorzy odzwierciedlający ludzkie potrzeby, jest elementem kształtowaniu pozytywnego „klimatu współpracy" tworzącego formy spajające i pomostowe kapitału społecznego (Theiss 2007, s. 16-17) i dobrostanu mieszkających ludzi. Formy wykluczające z kapitału społecznego są w przestrzeni pogranicza niepożądane. Prezentowane badania wykluczenia nie zidentyfikowały. Pokusa dzielenia na „swoich i obcych” nie jest czymś nowym w życiu społecznym; jednak razem nie znaczy tak samo. Różnorodność etniczno-regionalna nigdy nie jest zagrożeniem, ale szansą, zwłaszcza gdy czyni się coś dla wspólnego dobra.

\section{Bibliografia}

Balcer, E. (2018). Samowychowanie w ujęciu wybranych autorów XX w. Lublin: Towarzystwo Naukowe Katolickiego Uniwersytetu Lubelskiego.

Dahrendorf, D. (1991). Rozważania nad rewolucjq w Europie, Warszawa: Niezależna Oficyna Wydawnicza.

Frąckowiak, T. (2010). Funkcje pedagogiki społecznej w społeczeństwie mitu, wolności, demokracji i inteligentnej cywilizacji. Wybrane kwestie. W: J. Piekarski, T. Pilch, W. Theiss, D. Urbaniak Zając (red. nauk.), Edukacja społeczna wobec problemów współczesnego człowieka i społeczeństwa (s. 25-56). Łódź: Wydawnictwo Uniwersytetu Łódzkiego.

Kłoskowska, A. (1981). Socjologia kultury. Warszawa: PWN.

Kojder, A. (red.) (2007). Jedna Polska? Dawne i nowe zróżnicowania społeczne. Kraków: Wydawnictwo WAM.

Kopczyńska, M. (1993). Animacja społeczno-kulturalna: podstawowe pojęci i zagadnienia. Warszawa: Wydawnictwo Centrum Animacji Kultury.

Korniłowicz, K. (1930). Pomoc w tworzeniu jako zadanie pracy kulturalnej. W: K. Korniłowicz (red.), Zagadnienia oświaty dorosłych. Dwie konferencje (s. 64-85). Warszawa: Wydawnictwo Federacja Oświatowa Organizacyj Społecznych.

Krzysztofek, K., Szczepański, M.S. (2002). Zrozumieć rozwój. Od społeczeństw tradycyjnych do informatycznych: podręcznik socjologii rozwoju społecznego dla studentów socjologii, nauk politycznych i ekonomii. Katowice: Wydawnictwo Uniwersytetu Śląskiego. 
Lis, M. (2015). Mniejszość niemiecka na Śląsku Opolskim 1989-2014. Z bagażem przeszłości w realiach współczesności. Opole: Wydawnictwo Instytut Śląski.

Łodziński, S., Warmińska, K., Gudaszewski, G. (red.) (2015). Mniejszości narodowe i etniczne w Polsce w świetle Narodowego Spisu Powszechnego z 2011 roku. Warszawa: Wydawnictwo Naukowe Scholar.

Niżnik, J. (1983). Społeczne przesłanki projektowania działalności kulturalnej, wyd. 2 uzup. Warszawa: Centralny Ośrodek Metodyki Upowszechniania Kultury.

Nycz, E. (red.) (2005). Gmina Bierawa. Zarys monograficzny (od czasów najdawniejszych do początku XXI wieku). Opole: Wydawnictwo Instytut Śląski Sp.o.o.

Nycz E. (2008). Sołtysi '2006. Diagnoza roli i aktywności lokalnej. W: J. Kosowska-Rataj, E. Nycz (red.), Edukacyjny wymiar tożsamości kulturowej. Raporty z badań. Výchovně-vzdělávací rozměr kulturní identity. Zprávy z výzkumu, (s. 319-377). Opole: Wydawnictwo Instytut Śląski Sp.o.o.

Nycz, E. (2010). Polak - Ślq̨zak - Niemiec. Identyfikacje mieszkańców Ślq̨ska Opolskiego na poczq̨tku XXI wieku. W: R. Szwed, L. Dyczewski, J. Szulich-Kałuża (red.), Odmiany tożsamości (s. 55-70). Lublin: Wydawnictwo Katolickiego Uniwersytetu Lubelskiego.

Nycz E. (2013a). Animacja społeczno-kulturalna - między ideq a trudem codziennej realizacji. W: K. Nowak-Wolna, E. Nycz (red. nauk.), Kultura, animacja, zmiana społeczna (s. 95-111). Opole: Wydawnictwo Uniwersytetu Opolskiego.

Nycz, E. (2013b). Zmiana społeczna. Pomiędzy teoriami a codziennościq w animacji. W: K. Nowak-Wolna, E. Nycz (red. nauk.), Kultura, animacja, zmiana społeczna (s. 187-227). Opole: Wydawnictwo Uniwersytetu Opolskiego.

Radziewicz-Winnicki, A. (2004). Społeczeństwo w trakcie zmiany. Gdańsk: Gdańskie Wydawnictwa Psychologiczne.

Radziewicz-Winnicki, A. (2007). Modernizacja środowisk lokalnych w świetle zmiany społecznej. W: E. Marynowicz-Hetka (red.), Pedagogika społeczna: podręcznik akademicki, t. 2 (s. 58-88). Warszawa: Wydawnictwo Naukowe PWN.

Rychard, A. (1995). Ludzie i instytucje. Kto tworzy nowy ład? W: A. Sułek, J. Styk, I. Machaj (red.). Ludzie i instytucje. Stawanie się nowego ładu społecznego: pamiętnik IX Ogólnopolskiego Zjazdu Socjologicznego, Lublin 27-30 VI 1994, t. 1 (s. 25-34). Lublin: Wydawnictwo Uniwersytetu Marii Curie-Skłodowskiej.

Skrzypczak, B. (2006). Metoda animacji społecznej - zasadnicze aspekty dla praktyki edukacyjnej. W: W. Theiss, B. Skrzypczak (red.), Edukacja i animacja społeczna w środowisku lokalnym (s. 71-90). Warszawa: Centrum Wspierania Aktywności Lokalnej CAL.

Sołdra-Gwiżdż, T. (2010). Socjologia wobec Ślq̨ska - jedność czy wielość? Opole: Wydawnictwo Instytut Śląski.

Szczepański, M.S. (1992). Pokusy nowoczesności: polskie dylematy rozwojowe. Katowice: ,amp”.

Szczepański, M.S. (2001). Glokalny Ślq̨sk. W: E. Nycz, J. Kosowska-Rataj (red.), Dziedzictwo kulturowe pogranicza i samorzq̨dność w przemianach lokalnych Śląska Opolskiego (s. 13-17). Opole: Wydawnictwo Uniwersytetu Opolskiego.

Szczygielski, K. (2006). Geografia mniejszości narodowych i etnicznych w Polsce. Ujęcie ilościowe, Opole: Wydawnictwo Instytut Śląski. 
Szmeja, M. (2000). Niemcy? Polacy? Ślq̨zacy! Rodzimi mieszkańcy Opolszczyzny w świetle analiz socjologicznych. Kraków: „Uniwersitas”.

Sztompka, P. (2000). Trauma wielkiej zmiany. Społeczne koszty transformacji. Warszawa: Instytut Nauk Politologicznych Polskiej Akademii Nauk.

Sztompka, P. (2007). Zaufanie: fundament społeczeństwa. Kraków: Znak.

Sztompka, P. (2016). Kapitał społeczny. Teoria przestrzeni międzyludzkich. Kraków: Znak Horyzont.

Śmiełowska, M. (1999). Obecności etniczne i narodowe na Ślq̨sku Opolskim: procesy kształtowania tożsamości i relacji międzygrupowych. Opole: Wydawnictwo Uniwersytetu Opolskiego.

Theiss, M. (2007). Krewni - znajomi - obywatele: kapitał społeczny a lokalna polityka społeczna. Toruń: Wydawnictwo Adam Marszałek.

Touraine, A. (2010). O socjologii. Warszawa: Wydawnictwo Naukowe PWN.

Wnuk-Lipiński, E. (2008). Socjologia życia publicznego. Warszawa: Wydawnictwo Naukowe Scholar.

\section{Netografia}

http://www.polskawliczbach.pl/gmina_Dobrodzien\#dane-demograficzne\#ixzz4hvjtfDfD http://samorzad2014.pkw.gov.pl 